\title{
The Loss of Intercellular Adhesion Molecules in Breast Cancer: Does it Predict a Poor Prognosis?
}

\author{
Mahmoud Haj ${ }^{\mathrm{a}} \quad$ Arkadi Rappaport $^{\mathrm{a}} \quad$ Anatoli Hiat $^{\mathrm{a}} \quad$ Norman Loberant $^{\mathrm{b}} \quad$ Isaac Cohen $^{\mathrm{c}}$ \\ ${ }^{a}$ Department of Ambulatory Surgery and Breast Center, \\ ${ }^{b}$ Department of Diagnostic Radiology, \\ ${ }^{c}$ Department of Pathology, Western Galilee Hospital, Nahariya, Israel
}

Key Words

Breast cancer - Adhesive molecules - Expression . Prognosis

\section{Summary}

Background: Intercellular adhesive molecules are essential for the integrity of body tissue. A tumor's potential for invasion and metastasis depends on the structural changes of those molecules through the mutations of tumor cells. The aim of this study was to evaluate the expression of E-cadherin and $\beta$-catenin in breast carcinoma, and its effect on the outcome and survival of patients. Material and Methods: Immunohistochemical (IHC) staining of histological sections of different types of breast cancer for E-cadherin and $\beta$-catenin was performed in 88 breast tumors. Follow-up of the patients for a period of more than 5 years or until death was possible in all cases. Results: IHC staining for both E-cadherin and $\beta$-catenin was strongly positive in ductal carcinoma in situ (DCIS). Complete loss of expression was shown in $71 \%$ and $61 \%$ respectively, in infiltrating lobular carcinoma. Significant difference in loss of E-cadherin and/or $\beta$-catenin expression $(p<0.002$ ) was found between grade 2 and grade 3 invasive ductal carcinoma (IDC), regardless of tumor size, status of axillary nodes, age, or ethnicity. Conclusions: The loss of expression of adhesive molecules is correlated with the grade of IDC tumors and the type of breast tumor, and it is not an indicator of prognosis.

\author{
Schlüsselwörter \\ Brustkrebs · Adhesionsmoleküle · Expression · \\ Prognose
}

\section{Zuammenfassung}

Hintergrund: Interzelluläre Adhesionsmoleküle sind ausschlaggebend für die Integrität von Geweben. Das Potential eines Tumors zur Gewebeinvasion und Metastasierung hängt von strukturellen Änderungen dieser Moleküle durch Mutationen in Tumorzellen ab. Ziel dieser Studie war es, die Expression von E-Cadherin und $\beta$-Catenin in Mammakarzinomen im Hinblick auf Outcome und Überleben der Patienten zu untersuchen. Material und Methoden: Gewebeschnitte von 88 Mammakarzinomen verschiedener Art wurden zur Detektion von E-Cadherin und $\beta$-Catenin immunohistochemisch (IHC) gefärbt. In allen Fällen war ein Follow-up der Patienten über mehr als 5 Jahre bzw. bis zum Tode möglich. Ergebnisse: Bei duktalen Karzinomen in situ (DCIS) war die IHC-Färbung für sowohl E-Cadherin als auch $\beta$-Catenin stark positiv. Kompletter Verlust der Expression konnte in 71\%, beziehungsweise in $61 \%$ der invasiv lobulären Karzinome gezeigt werden. Ein signifikanter Unterschied ( $p<0.002)$ im Verlust der Expression von E-Cadherin und/oder $\beta$-Catenin bestand zwischen invasiv duktalen Karzinomen (IDC) zweiten und dritten Grades; ein Zusammenhang mit Tumorgröße, Status der Achsellymphknoten, Alter oder Ethnizität bestand nicht. Schlussfolgerungen: Verlust der Expressions von Adhesionsmolekülen korreliert mit dem Grad der IDC-Tumore sowie dem Mammakarzinomstyp, besitzt jedoch keine prognostische Aussagekraft.

\begin{tabular}{|c|c|}
\hline KARGER & (C) 2007 S. Karger GmbH, Freiburg \\
\hline $\begin{array}{l}\text { Fax +49761 } 4520714 \\
\text { E-mail Information@Karger.de } \\
\text { www.karger.com }\end{array}$ & $\begin{array}{l}\text { Accessible online at: } \\
\text { www.karger.com/brc }\end{array}$ \\
\hline
\end{tabular}

Mahmoud Haj, MD 


\section{Introduction}

Breast cancer is the most common malignancy in women, and the second cause of cancer mortality after lung cancer [1]. Breast cancer, like other malignant tumors, is characterized by uncontrolled cell growth, detachment and migration of malignant cells to invade adjacent tissues, regional lymph nodes, and distant organs, where they become an established metastasis [2]. Understanding the mechanism of intercellular adhesiveness might help elucidate the metastatic process.

Intercellular adhesion molecules that link between homotypic cells are essential for the preservation of tissue integrity. Diverse adhesion molecules and receptors control most of the human and mammalian vital phenomena, including embryogenesis, cellular differentiation and wound healing. During the last decades, there has been an increasing interest in the structure and function of these molecules that mediate cell-to-cell and cell-to-matrix adhesion in normal tissues and in malignancy. Researchers have found that adhesion molecules play a role in the behavior of invasion and metastasis of malignant tumors [3]. The adherens junction functions to maintain the normal phenotype of these cells, and it is responsible for the strong cell-cell adhesion that promotes epithelial polarity and prevents migration of epithelial cells away from their appropriate location $[4,5]$. E-cadherin (E-cad), a subclass of the cadherin family, is the transmembrane component of the adherens junction in most epithelial cells. E-cad is a calcium-regulated glycoprotein that has been studied intensively. As a transmembrane molecule, its extracellular domain is involved in cell-cell adhesion, while the intracellular domain is connected to the actin cytoskeleton through the catenins (alpha, beta, and gamma catenin) $[6,7]$. Loss of expression or function of any part of the E-cad-catenin-cytoskeleton complex results in the loss of intercellular adhesion, loss of polarity and architecture; thus, detached cells become able to migrate from their main location in epithelial tissue $[8,9]$. Alteration in the expression of catenins can be demonstrated despite preserved, although non-functional, E-cad expression. Decrease or loss of functional E-cad in tumor tissue is thought to be a step in the metastatic behavior of malignant epithelial tumors.

In breast cancer, an inverse relationship has been found between levels of E-cad expression and metastasis, tumor grade, and outcome. Although it has been noted that decreased expression of E-cad alone may have a limited value as a prognostic indicator [10], examining the entire repertoire of cadherins and catenins expressed by tumors may, in fact, provide useful prognostic information. Functional E-cad acts as a suppressor molecule of tumor invasiveness; thus, its expression is related to the invasive character, and it has been referred to as the 'suppressor-of-invasion gene' [11]. The gene has been cloned and is located on chromosome 16q22.1 [12]. Decreased cadherin adhesive function can result from mutations in genes encoding the catenins. For example, perturbation or mutations in $\beta$-catenin that disrupt its binding to E-cad result in a non- adhesive phenotype [13]. The loss of E-cad expression by breast cancer cells appears to involve multiple mechanisms, including complete or partial gene depletion, methylation, and chromatin rearrangement [reviewed in 10]. E-cad expression is higher in well-differentiated invasive ductal carcinomas (IDCs), as opposed to poorly differentiated or invasive lobular tumors $[14,15]$. While E-cad expression has been correlated with a high degree of tumor differentiation, it has been found to be independent of lymph node status and tumor size [16]. The aim of this study was to evaluate the correlation between the loss of E-cad and/or $\beta$-catenin and the histological type and grade of breast cancer, the metastatic status of these tumors and the 5-year survival of the patients.

\section{Patients and Methods}

\section{Patients}

Included in this study were 85 patients with breast cancer who underwent surgery in 1999-2000 at our hospital. 3 patients had bilateral and 82 patients unilateral breast carcinoma. All patients were available for followup for 5 years after diagnosis and surgery or until death. Patient age ranged from 28 to 88 years at the time of diagnosis of breast cancer. $20 \%$ of the patients were premenopausal, and $30 \%$ were older than 70 years. $87 \%$ were Jewish, and $13 \%$ were Arabs. In each case, tissue sections of the primary tumor were prospectively prepared and reviewed by 2 pathologists. Histology showed the diagnosis of ductal carcinoma in situ (DCIS) in 10 cases, invasive lobular carcinoma (ILC) in 14 cases, IDC in 57 cases, and miscellaneous types of breast cancer (medullary, tubular, papillary, and undifferentiated carcinoma) in 7 cases. The latter were excluded because the number of this group was too small to draw conclusions. Bilateral breast cancer was found in 3 patients: 1 with bilateral DCIS, 1 with bilateral ILC, and 1 with bilateral IDC. Estrogen (ER) and progesterone (PgR) receptor expression and HER-2/neu expression were assessed in all cases.

\section{Immunohistochemical (IHC) Analysis}

Formalin-fixed, paraffin-embedded tissue blocks were prepared from all tumors included in this study. Tissue sections $5 \mu \mathrm{m}$ thick were cut, deparaffinized, and treated with immunoperoxidase using the avidin-biotin complex method after high temperature antigen unmasking with the microwave technique, using EDTA buffer with the specific monoclonal antibody: the monoclonal mouse anti-human estrogen $\alpha$ (Dako A/S, Glostrup, Denmark), monoclonal mouse antihuman progesterone receptor, clone PgR 636 (DAKO Co., Carpinteria, CA, USA), mouse antiHER-2(c-erbB-2) antibody, clone TAB 250, mouse anti-E-cadherin, clone 4A2C7, and monoclonal mouse anti- $\beta$-catenin, clone CAT-5H10 (Zymed Laboratories, South San Francisco, CA, USA). 2 pathologists examined the specific IHC-stained sections for ER, PgR, HER-2, E-cad, and $\beta$-catenin, respectively. The intensity of the staining of each slide section was scored on a 4 -tier scale $(0,+,++,+++)$.

\section{Results}

The expression of E-cad and $\beta$-catenin was not affected by the age or ethnicity of the patients. ER, PgR, and HER-2/neu also seem to be unrelated to the changes in the level of E-cad or $\beta$-catenin expression in the malignant breast cells. In the 10 cases of DCIS, the IHC staining was strong (+++) in 100\% 
Table 1. Breast tumors included in this study and the Immunohistochemical (IHC) staining results

\begin{tabular}{|c|c|c|c|c|c|c|}
\hline \multirow[t]{2}{*}{ Tumor } & \multirow{2}{*}{$\begin{array}{l}\text { Breast } \\
\text { tumors, } \mathrm{n}\end{array}$} & \multirow{2}{*}{$\begin{array}{l}\text { Patients, } \\
\mathrm{n}\end{array}$} & \multicolumn{2}{|c|}{ E-cadherin } & \multicolumn{2}{|c|}{ B-catenin } \\
\hline & & & $\mathrm{N}, \%$ & $\mathrm{D} / \mathrm{L}, \%$ & $\mathrm{~N}, \%$ & $\mathrm{D} / \mathrm{L}, \%$ \\
\hline DCIS & 10 & 9 & 100.0 & - & 90.0 & 10.0 \\
\hline ILC & 14 & 13 & 29.0 & 71.0 & 39.0 & 61.0 \\
\hline \multicolumn{7}{|l|}{ IDC } \\
\hline Grade 2 & 27 & 27 & 63.0 & 37.0 & 63.0 & 37.0 \\
\hline Grade 3 & 30 & 29 & 16.7 & 83.3 & 66.7 & 33.3 \\
\hline Miscellaneous & 7 & 7 & - & - & - & - \\
\hline
\end{tabular}

$\mathrm{N}=$ normal; $\mathrm{D} / \mathrm{L}=$ decreased or loss of expression, $\mathrm{DCIS}=$ ductal carcinoma in situ; $\mathrm{ILC}=$ invasive lobular carcinoma; IDC = invasive ductal carcinoma.
Table 2. Immunohistochemical (IHC) staining of 14 invasive lobular carcinomas (ILC) of 13 patients in relation to tumor size, metastatic lymph nodes, and 5-year survival

\begin{tabular}{llllll}
\hline $\begin{array}{l}\text { Tumor } \\
(14 \mathrm{~T} / 13 \mathrm{P})\end{array}$ & $\begin{array}{l}\text { E-cadherin } \\
\text { loss }\end{array}$ & $\begin{array}{l}\text { B-catenin } \\
\text { loss }\end{array}$ & $\begin{array}{l}\text { Tumor size } \\
>2 \mathrm{~cm}\end{array}$ & $\begin{array}{l}\text { Axillary lymph } \\
\text { node metastases }\end{array}$ & 5-year survival \\
\hline ILC & $71 \%$ & $61 \%$ & $57 \%$ & $43 \%$ & $86 \%$ \\
\hline
\end{tabular}

Table 3. Loss of E-cadherin and B-catenin in invasive ductal carcinomas (IDC)

\begin{tabular}{llllllll}
\hline Tumor type & $\begin{array}{l}\text { Patients, } \\
\mathrm{n}\end{array}$ & $\begin{array}{l}\text { Loss of E-cad } \\
\text { and/or B-cat, \% }\end{array}$ & $\mathrm{p}$ & $\begin{array}{l}\text { Loss of } \\
\text { E-cad, \% }\end{array}$ & $\mathrm{p}$ & $\begin{array}{l}\text { Loss of } \\
\text { B-cat, \% }\end{array}$ & $\mathrm{p}$ \\
\hline Grade 2 & 27 & 59.3 & $0.002^{\mathrm{a}}$ & 37.0 & $<<0.001^{\mathrm{c}}$ & 37.0 & $0.788 \mathrm{~b}$ \\
Grade 3 & 30 & 86.7 & & 83.3 & & 33.3 & \\
Tumor size $<2 \mathrm{~cm}$ & 32 & 71.9 & $0.771^{\mathrm{b}}$ & 59.4 & $0.944^{\mathrm{b}}$ & 25.0 & $0.064 \mathrm{a}$ \\
Tumor size $>2 \mathrm{~cm}$ & 25 & 76.0 & & 64.0 & & 48.0 & \\
Involved axillary nodes & 23 & 43.9 & $0.756^{\mathrm{a}}$ & 69.5 & $0.878^{\mathrm{d}}$ & 30.4 & $0.572 \mathrm{~b}$ \\
Free & 32 & 56.1 & & 56.3 & & 40.6 & \\
\hline
\end{tabular}

${ }^{\mathrm{a}}$ Chi-square test, 1 -sided.

${ }^{\mathrm{b}}$ Chi-square test, 2-sided.

${ }^{\mathrm{c}}$ Wilcoxon rank sum test, 1 -sided.

${ }^{\mathrm{d}}$ Wilcoxon rank sum test, 2 -sided.

E-cad $=$ E-cadherin $;$ B-cat $=\beta$-catenin .

of cases for E-cad and in $90 \%$ for $\beta$-catenin. Complete loss of E-cad expression and $\beta$-catenin was encountered in $71 \%$, and in $61 \%$ of ILC, respectively. $57 \%$ of ILC tumors were larger than $2 \mathrm{~cm}$ in diameter, and axillary lymph node metastases were found in $43 \%$ of ILC cases. 57 IDC tumors included 27 grade 2 and 30 grade 3 according to the Bloom and Richardson classification (tables 1 and 2).

The 3 dimensions of each tumor were registered in the pathology report. The largest dimension of each tumor was defined in this study as the tumor size. 32 tumors $(56.1 \%)$ were less than $2 \mathrm{~cm}$, and 25 (43.9\%) tumors were larger than $2 \mathrm{~cm} .55$ patients had undergone complete axillary lymph node dissection in addition to either mastectomy or lumpectomy according to the surgical indications and to the preference of the patient. 1 patient with bilateral breast IDC had no lymph node analysis. Metastatic involvement of axillary nodes was encountered in 23 cases $(41.8 \%)$ ). 10 of the 30 tumors smaller than $2 \mathrm{~cm}(33.3 \%)$ and 13 of 25 tumors larger than $2 \mathrm{~cm}$ $(52.0 \%)$ had already metastasized to the axillary nodes at the time of surgery. IHC staining for E-cad and $\beta$-catenin was negative in 6 IDC tumors; negative staining only to E-cad was found in 10 IDC cases; and negative staining only for $\beta$ catenin in 14 tumors. Hence, a loss of expression of E-cad and/or $\beta$-catenin was detected in 30 out of 57 tumors (52.6\%). Partial loss of E-cad was shown in 19 IDC tumors (33\%). Complete loss of E-cad was detected in 9 tumors smaller than $2 \mathrm{~cm}$, and in 7 tumors larger than $2 \mathrm{~cm}$. Complete loss of $\beta$ catenin was found in 8 tumors smaller than $2 \mathrm{~cm}$, and in $12 \mathrm{tu}-$ mors larger than $2 \mathrm{~cm}$. Metastatic axillary lymph nodes were found in 6 of 26 grade 2 IDC tumors (23.1\%), and in 17 of 29 grade 3 IDC tumors $(58.6 \%)$.

Loss of E-cad expression was found in 11 out of 32 tumors (34.4\%) with negative axillary lymph nodes, and in 5 out of 23 tumors $(21.7 \%)$ with metastatic nodes. Loss of $\beta$-catenin was 
Table 4. Patient survival and loss of adhesive molecules expression

\begin{tabular}{llll}
\hline Survival & $\begin{array}{l}\text { Loss of } \\
\text { E-cad, \% }\end{array}$ & $\begin{array}{l}\text { Loss of } \\
\text { B-cat, \% }\end{array}$ & $\begin{array}{l}\text { Loss of both E-cad } \\
\text { and B-cat, \% }\end{array}$ \\
\hline$<5$ years & 71.5 & 57.1 & 83.7 \\
$>$ 5 years & 79.2 & 60.0 & 76.0 \\
p (Fisher's exact test) & 0.253 & 0.207 & 0.685 \\
\hline
\end{tabular}

E-cad $=$ E-cadherin $;$ B-cat $=\beta$-catenin .

found in 13 of 32 tumors (40.6\%) with negative axillary nodes, and in 7 of 23 tumors $(30.4 \%)$ with metastatic nodes. Statistical analysis showed that the loss of E-cad is more prominent in grade 3 IDC than in grade 2 IDC (Wilcoxon rank sum test, $\mathrm{p}<<0.001)$. Although the loss of $\beta$-catenin in grade 3 IDC was more common than in grade 2 IDC, the difference was statistically non-significant (chi-square test, $\mathrm{p}=0.788$ ). Comparing the loss of E-cad and/or $\beta$-catenin in grade 3 to that in grade 2 IDC also revealed a significant difference (chi-square test, $\mathrm{p}=0.02$ ). When using both tests (chi-square test and Wilcoxon rank sum test) the loss of E-cad and/or $\beta$-catenin was found to be non-related to the size of the tumor or to the involvement of axillary lymph nodes by metastases. Decreased expression of $\beta$-catenin was noticed in association with larger tumor size ( $>2 \mathrm{~cm}$ compared to tumors $<2 \mathrm{~cm}$ ) but statistically, it was non-significant (chi-square test $\mathrm{p}=0.064$ ) (table 3 ). 10 patients died less than 5 years after breast cancer diagnosis. 1 patient with ILC and 7 patients with IDC grade 3 died due to disseminated breast cancer metastases. 2 patients with IDC grade 2 died due to second primary cancer: 1 developed pancreatic cancer, and the second developed gastric cancer. Overall 5-year survival of the patients with IDC included in this study was $84.2 \%$.

Table 4 demonstrates the IHC of IDC tumors for patients who survived less or more than 5 years and shows that the difference in loss of intercellular adhesion molecules was statistically non-significant. This may indicate that loss or preservation of intercellular adhesion molecules per se, in breast carcinomas, has no significant effect on patients' survival.

\section{Discussion}

Intercellular adhesion molecules that preserve the integrity of epithelial tissue have been intensively studied. In adult organisms, the cadherin-catenin adhesion system maintains the differentiated state of the tissues and suppresses tumor development [11, 17-20]. Alterations in the cadherin-catenin cell-cell adhesion system are associated with loss of differentiation and tumor formation, increased invasiveness, metastasis, and unfavorable prognosis for patients with breast carcinoma [21, 22]. In our study, we have examined this hypothesis in different types, grades, and stages of breast cancer. IHC staining for
E-cad and $\beta$-catenin was performed in 88 cases of breast cancer. Strong normal expression of these 2 adhesion molecules was found in all DCIS cases $(n=10)$. This result supports the fact that DCIS behaves as a non-invasive and non-metastatic disease.

Loss of E-cad and/or $\beta$-catenin was strikingly prominent in cases of ILC (71 and $61 \%$, respectively), comparing favorably with other published reports. In 2 cases, several foci of highgrade DCIS were found adjacent to ILC. $43 \%$ of ILC cases were associated with axillary lymph node metastases. It has been suggested that loss of E-cad is an early event in lobular breast cancer, occurring even in lobular carcinoma in situ [23]. In fact, lobular carcinomas have been associated with germ line mutations in E-cad. The striking loss of E-cad in lobular carcinoma may explain the distinctive growth pattern but is not associated with excessively high rate of metastasis. E-cad loss in the majority of lobular carcinomas results from loss of heterozygosity of the E-cad gene (CDH1) together with mutations over the coding region [23-25].

The loss of E-cad and $\beta$-catenin expression in 57 cases of IDC was significantly higher in grade 3 than in grade 2 tumors. Axillary lymph node metastases were found in $23.1 \%$ (6/26 cases) of grade 2 IDC compared to $58.6 \%$ (17/29 cases) of grade 3 tumors. This result may indicate a correlation between highgrade tumor, loss of E-cad and/or $\beta$-catenin, and the metastatic features of mammary IDC. Statistical analysis did not show a correlation between loss of E-cad and/or $\beta$-catenin and the size of the primary tumor or per se nodal metastases. Paradoxical results were also found in small tumors $(>2 \mathrm{~cm}$ in diameter). Irrespective of the degree of tumor differentiation and size, a decreased E-cad expression was found in 34.4\% non-metastatic tumors, and in $21.7 \%$ of cases with axillary nodal metastasis.

A similar paradox has been reported. It was concluded that loss of E-cad expression is not the only, or even the most important factor involved in the metastatic process. E-cad immunopositivity shows a wide range in both metastatic and non-metastatic breast tumors; thus, it is most unlikely that measurement of E-cad expression alone will be capable of accurate prognostication in an individual case. It might be explained by E-cad immunopositivity not differentiating between functional and non-functional E-cad [26]. In a study of E-cad expression in sections of normal human mammary glands and breast carcinoma, a correlation between reduced E-cad expression and a poor degree of differentiation was found. In that studies, all IDC, including poorly differentiated cases, retained some expression of E-cad in contrast to other tumor types such as colonic and prostatic adenocarcinomas and head and neck squamous cell carcinomas, which, when poorly differentiated, were reportedly often completely E-cad-negative [27-29]. Full functional activity of E-cad is dependent on catenin binding. Certain mutations in the E-cad gene or changes in the E-cad-associated cytoplasmic proteins, the catenins, might just weaken the adhesive capability of the 
molecule. Thus, reduced E-cad expression in some breast cancers could be due to a direct mutation in the E-cad gene [29]. When E-cad, $\beta$-catenin, $\alpha$-catenin or plakoglobin, are all analyzed as one group, reduction of at least 1 of these markers did correlate significantly with metastases of breast carcinoma [30].

In our study, 5 of 7 patients $(71.3 \%)$ with metastatic IDC grade 3 who survived less than 5 years, had a decreased E-cad and/or $\beta$-catenin expression, compared to decreased expression in $87 \%$ of similar tumors of patients who survived more than 5 years. This result shows the discrepancy between loss of adhesion molecule expression and patient survival. One study of E-cad mRNA expression in breast carcinomas showed that tumors with preserved E-cad expression tend not to disseminate whereas those with impaired E-cad expression tend to metastasize [31]. It was found, in contrast to other studies [32], that the survival of non-metastatic patients correlates with E-cad expression $(p=0.007)$. Furthermore, decreased expression was related to disease-free survival for the whole population studied $(\mathrm{p}=0.0065)$ and the non-metastatic women $(\mathrm{p}=0.0059)$.

There are conflicting opinions about the prognostic value of altered IHC patterns of E-cad. Some studies have found a correlation between reduced E-cad expression (particularly in node-negative patients) and their survival, while others have found it of little value in predicting clinical behavior of those patients. Thus, the usefulness of E-cad alone in this aspect is still under debate. Breast cancers with reduced or missing Ecad also can exhibit reduced catenins. One study indicated that $\alpha$-catenin was reduced more frequently than E-cad in breast cancer [33]. The authors suggested that $\alpha$-catenin may serve as a marker for disturbances in the adhesive function of E-cad.

In our study, we did not find a statistically significant difference between smaller and larger tumors in both grade 2 and grade 3 in E-cad and/or catenin expression (table 3). Thus, it is apparent that the size of the IDC breast tumor is not essentially associated with loss of adhesion molecule expression. Furthermore, no statistical difference was found between decreased expression and involvement of axillary lymph nodes by metastases. This result may indicate that the cadherincatenin-cytoskeleton complex is not the only mechanism that controls the invasiveness and metastasis of breast cancer. Cell motility factors, like scatter factor/hepatocyte growth factor and acidic fibroblast growth factor, have been found to induce invasiveness of diverse epithelial cell lines in vitro without changing the E-cad expression. Such components might also play an important role in the invasion of E-cad-positive IDCs [34, 35].

Re-expression of adhesion molecules such as E-cad, $\alpha$ - and $\beta$-catenins in metastatic lesions is a significant finding that demonstrates the capability of metastatic cells, after their detachment and re-growth elsewhere, to re-express their adhesion molecules [36]. Increased E-cad expression in lymph node metastases of IDC was strongly associated with improved survival, whereas expression in primary tumors was not [37]. IHC assessment of E-cad expression using tissue microarray technology in a series of 1,665 cases of invasive nonlobular breast carcinoma showed that reduction of E-cad expression was associated with reduced disease-free interval and overall survival. It was found to be an indicator of poor prognosis in larger tumors, higher histological grade, and development of distant metastases. These results suggest that reduction of E-cad expression in IDC might be an important factor in disease progression, metastases, recurrence, and poor prognosis [38].

Varied results obtained by researchers might be due to the variety of the laboratory settings and the number of cases in each series. Our series is a small one, and the results differ somewhat from those of large series. Both a larger population and longer follow up might narrow the gap between our results and those of larger series.

\section{References}

1 Berg JW, Hutter RVP: Breast cancer. Cancer 1995; 75:257-269.

2 Liotta LA, Kohn E: Cancer invasion and metastasis. JAMA 1990;263:1123-1126.

$\checkmark 3$ Takeichi M: Cadherins: a molecular family important in selective cell-cell adhesion. Annu Rev Biochem 1990;59:237-252.

$\checkmark 4$ Boller K, Vesweber D, Kemler R: Cell adhesion molecule uvomorulin is localized in the intermediate junctions of adult intestinal epithelial cells. $\mathrm{J}$ Cell Biol 1985;100:327-332.

$\checkmark 5$ Kemler R, Ozawa M, Ringwald M: Calcium dependent cell adhesion molecules. Curr Opin Cell Biol 1989;1:892-897.

6 Nagafuchi A, Takeichi M: Cell binding function of E-cadherin is regulated by the cytoplasmic domain. EMBO J 1988;7:3679-3684.
7 Ozawa M, Baribault H, Kemler R: The cytoplasmic domain of the cell adhesion molecule uvomorulin associates with three independent proteins structurally related in different species. EMBO J 1989; 8:1711-1717.

8 Jiang WG: E-cadherin and its associated protein catenins, cancer invasion and metastases. Br J Surg 1996;83:437-446.

9 Takayama T, Shiozaki H, Inoue M, Oka H, Tamura S, Takatsuka Y, Mori T: Expression of E-cadherin and alpha catenin molecules in human breast cancer tissues and association with clinicopathological features. Int J Oncol 1994;5:775-780.

10 Wheelock MJ, Soler AP, Knudsen KA: Cadherin junctions in mammary tumors. J Mammary Gland Biol Neoplasia 2001;6:275-285.

11 Vleminckx K, Vakaet L Jr, Mareel M, Fiers W, van Roy F: Genetic manipulation of E-cadherin expression by epithelial tumor cells reveals an invasion suppressor role. Cell 1991;66(abstr):107-119.
12 Berx G, Staes K, van Hengel J, Molemans F, Bussemakers MJ, van Bokhoven A, van Roy F: Cloning and characterization of the human invasion suppressor gene E-cadherin(CDH1). Genomics 1995; 26:281-289.

13 El-Bahrawy MA, Pignatelli M: E-cadherin and catenins: molecules with versatile roles in normal and neoplastic epithelial cell biology. Microsc Res Tech 1998;43:224-232.

14 Oka H, Shozaki H, Kobayashi K, Inoue M, Thara H, Kobayashi T, Takatsuka Y, Matsuyoshi N, Hirano S, Takeichi M, Mori T: Expression of E-cadherin cell adhesion molecules in human breast cancer tissues and its relationships to metastasis. Cancer Res 1993;53:1696-1701.

15 Gupta SK, Douglas-Jones AG, Jasani B, Morgan JM, Pignatelli M, Mansel RE: E-cadherin (E-cad) expression in duct carcinoma in-situ (DCIS) of the breast. Virchows Arch 1997;430:23-28. 
16 Charpin C, Garcia S, Bouvier C, Devictor B, Andrac L, Choux R, Lavaut M: E-cadherin quantitative IHC assay in breast carcinomas. J Pathol 1997; 181:294-300.

17 Behrens J, Vakaet L, Friis R, Winterhager E, van Roy FM, Mareel MM, Birchmeier W: Loss of epithelial differentiation and gain of invasiveness correlates with tyrosine phosphorylation of the E-cadherin/beta-catenin complex in cells transformed with a temperature-sensitive v-SRC gene. J Cell Biol 1993;120:757-766.

18 Hedrick L, Cho KR, Vogelstein B: Cell adhesion molecules as tumor suppressors. Trends Cell Biol 1993:3:36-39.

19 Peifer M: Cancer, catenins, and cuticle pattern: a complex connection. Science 1993;262:1667-1668.

20 Takeichi M: Cadherins in cancer: implications for invasion and metastasis. Curr Opin Cell Biol 1993; 5:806-811.

21 Sommers CL, Thompson EW, Torri JA, Kemler R, Gelmann EP, Byers W: Cell adhesion molecule unomorulin expression in human breast cancer cell lines: relationship to morphology and invasive capacities. Cell Growth Diff 1991;2:365-372.

-22 Siitonen SM, Kononen JT, Helin HJ, Rantala IS, Holli KA, Isola JJ: Reduced E-cadherin expression is associated with invasiveness and unfavorable prognosis in breast cancer. Am J Clin Pathol 1996; 105:394-402.

23 Vos CB, Cleton-Jansen AM, Berx G, de Leeuw WJ, ter Haar NT, Vn Roy F, Cornelisse CJ, Peterse JL, van de Vijver MJ: E-cadherin inactivation in lobular carcinoma in situ of the breast: an early event in tumorigenesis. Br J Cancer 1997;76:1131-1133.

-24 Berx G, Becker KF, Hofler H, van Roy F: Mutations of the human E-cadherin (CDH1) gene. Hum Mutat 1998;12:226-237.
25 De Leeuw WJ, Berx G, Vos CB, Peterse JI, van de Vijver MJ, Litvinov S, van Roy F, Cornelisse CJ, Cleton-Jansen AM: Simultaneous loss of E-cadherin and catenins in invasive lobular carcinoma in situ. J Pathol 1997;183:404-411.

26 Hunt NCA, Douglas-Jones AG, Jasani B, Morgan JM, Pignatelli M: Loss of E-cadherin expression associated with lymph node metastases in small breast carcinomas. Virchows Arch 1997;430: 285-289.

27 Moll R, Mitze M, Frixen UH, Birchmeier W: Differential loss of E-cadherin expression in infiltrating ductal and lobular breast carcinomas. Am J Pathol 1993;143:1731-1742.

28 Van der Wurff AA, ten Kate J, van der Linden EP, Dinjens WN, Arends JW, Bosman FT: L-CAM expression in normal, premalignant and malignant colon mucosa. J Pathol 1992;168:287-291.

29 Umbas R, Schalken JA, Aalders TW, Carter BS, Karthaus HF, Schaafsma HE, Debruyne FM, Isaacs WB: Expression of the cellular adhesion molecule E-cadherin is reduced or absent in high grade prostate cancer. Cancer Res 1992;52:5104-5109.

30 Buckholm IK, Nesland JM, Karesen R, Jacobsen U, Borresen-Dale AL: E-cadherin and alpha-, betaand gamma-catenin protein expression in relation to metastasis in human breast carcinoma. J Pathol 1998;185:262-266.

31 Guriec N, Marcellin L, Gairard B, Calderoli H, Wilk A, Renaud R, Bergerat JP, Oberling F: E-cadherin mRNA expression in breast carcinomas correlates with overall and disease-free survival. Invasion Metastasis 1996;16:19-26.
32 Lipponen P, Saarelainen E. Ji H, Aaltomaa S, Syrjanen K: Expression of E-cadherin (E-CD) as related to other prognostic factors and survival in breast cancer. J Pathol 1993;174:101-109.

33 Rimm DL, Sinard JH, Morrow JS: Reduced alphacatenin and E-cadherin expression in breast cancer. Lab Invest 1995;72:506-512.

34 Weinder KM, Behrens J, Vandekerchkhove J, Birchmeier W: Scatter factor: molecular characteristics and effect on the invasion of epithelial cells. J Cell Biol 1990;111:2097-2108.

35 Weidner KM, Arakaki N, Hartmann G, Vandekerckhove J, Weingart S, Rieder H, Fonatsch C, Tsubouchi H, Hishida T, Daikuhara Y, Birchmeier W: Evidence for the identity of human scatter factor and human hepatocyte growth factor. Proc Natl Acad Sci USA 1991;88:7001-7005.

36 Bukholm IK, Nesland JM, Borresen-Dale AL: Reexpression of E-cadherin, alpha-catenin and betacatenin but not gamma-catenin, in metastatic tissue from breast cancer patients. J Pathol 2000;190: 15-19.

37 Harigopal M, Berger AJ, Camp RL, Rimm DL, Kluger HM: Automated quantitative analysis of Ecadherin expression in lymph node metastases is predictive of survival in invasive ductal breast cancer. Clin Cancer Res 2005;11:4083-4089.

38 Rakha EA, Abd El Rehim D, Pinder SE, Lewis SA, Ellis IO: E-cadherin expression in invasive non-lobular carcinoma of the breast and its prognostic significance. Histopathol 2005;46:685-693. 